\title{
B12 Clonagem e expressão do hormônio do crescimento humano recombinante (hGH) em Escherichia coli
}

Thiago Santos Chaves ${ }^{1}$, Daniel Tait Vareschini ${ }^{2}$, Fernanda de Almeida ${ }^{2}$, Cristiane Pinheiro Pestana², Haroldo Cid da Silva Junior², Marco Alberto Medeiros²

1 Vice-Diretoria de Desenvolvimento Tecnológico, Laboratório de Tecnologia Recombinante, Bio-Manguinhos, Fundação Oswaldo Cruz, Rio de Janeiro, Brasil - Centro Universitário Estadual da Zona Oeste 2 Vice-Diretoria de Desenvolvimento Tecnológico, Laboratório de Tecnologia Recombinante, Bio-Manguinhos, Fundação Oswaldo Cruz, Rio de Janeiro, Brasil

Introdução: $\mathrm{O}$ hGH (Human growth hormone) é um polipeptídio de cadeia simples com 191 resíduos de aminoácidos. Em Junho de 2013, o Ministério da Saúde Brasileiro anunciou parcerias entre laboratórios públicos e privados para incentivo da produção nacional de biofármacos, entre eles a somatropina, nome comercial dado ao hGH. Com o objetivo de desenvolver competências e qualificar profissionais para atuar no desenvolvimento e acompanhamento de novos processos relacionados a este produto foi realizado o trabalho de otimização de códon, clonagem e expressão de hGH recombinante em E. coli, desde a construção in silico até o crescimento e expressão em escala de bancada.

Objetivo: Este trabalho tem como objetivo obter hGH recombinante.

Metodologia: $\mathrm{O}$ gene que codifica o $\mathrm{hGH}$, foi avaliado in silico e os códons otimizadospara expressão em $E$. coli. O gene foi amplificado por PCR, o amplicon purificado e digerido com as enzimas de restrição $\mathrm{Ncol}$ e HindIII, clonado no vetor de expressão e amplificado em E. coli TOPO10. A clonagem foi confirmada por PCR e sequenciamento de nucleotídeos demostrando identidade. Os clones positivos foram expandidos e o hormônio recombinante expresso em E. coli BL21 star DE3 em meio Terrific Broth (TB) contendo canamicina e IPTG. Os ensaios de expressão foram realizados em shaker e biorreator.

Resultados: A sequência de hGH foi otimizada para a expressão em E. coli obtendo um CAI (Codon Adaptation Index) de 0,76. O gene foi amplificado por PCR e analisado em gel de agarose confirmando o tamanho do amplicon gerado. $\mathrm{O}$ amplicon foi purificado, quantificado e clonado no vetor de expressão. O produto da clonagem foi transformado em E. coli TOP10 resultando, após seleção, em 3 clones recombinantes, confirmados por PCR e sequenciamento. Os clones foram expandidos, seu DNA extraído e utilizado para transformação em E. coli BL21 para expressão. Um dos clones obtidos em E. coli BL21 foi cultivado em shaker em meio TB suplementado com canamicina a uma temperatura de $37^{\circ} \mathrm{C}$ e induzido com IPTG a $28^{\circ} \mathrm{C}$ 
com agitação de $200 \mathrm{rpm}$, produzindo $0,6 \mathrm{~g} / \mathrm{L}$ de proteína solúvel, representado $76 \%$ da proteína total expressa no extrato bruto. $\mathrm{Na}$ condição de cultivo em biorreator, com aeração de 1 vvm e 6 horas de cultivo, sendo 4 de indução, obtivemos $1 \mathrm{~g} / \mathrm{L}$, mantendo a solubilidade e atingindo um aumento de $40 \%$ em relação ao cultivo em shaker.

Conclusão: Utilizando condições padrões do laboratório, conseguimos demonstrar a expressão de hGH recombinante em $E$. coli, solúvel e em alta concentração, $1 \mathrm{~g} / \mathrm{L}$ de cultura. Este resultado confirma a qualificação para o desenvolvimento de novos insumos e processos dentro da Unidade. Cabe ressaltar que experimentos de otimização utilizando planejamento experimental poderão aumentar ainda mais a produtividade do hormônio em reatores.

Palavras-Chave: hGH, Biofármacos, Expressão, Clonagem 